\title{
Requirement of nitrogen for wheat-mungbean cropping sequence under strip tillage system at two residue retention levels
}

\author{
Md Mustafizur Rahman ${ }^{1}$, Mohammad Monirul Hasan Tipu ${ }^{2 *}$, Raunak Jahan ${ }^{3}$, Jubaidur Rahman ${ }^{4}$, Razia Sultana ${ }^{5}$ \\ and Md Rafiqul Islam ${ }^{1}$
}

\begin{abstract}
${ }^{1}$ Department of Soil Science, Bangladesh Agricultural University, Mymensingh-2202, Bangladesh
${ }^{2}$ Plant Pathology Division, Bangladesh Agricultural Research Institute (BARI), Joydebpur, Gazipur-1701, Bangladesh

${ }^{3}$ Department of Aquaculture, Bangladesh Agricultural University (BAU), Mymensingh-2202, Bangladesh

${ }^{4}$ Agronomy Division, Regional Agricultural Research Station, Bangladesh Agricultural Research Institute (BARI), Jamapur2000, Bangladesh

${ }^{5}$ Agricultural Economics Division, Bangladesh Institute of Nuclear Agriculture (BINA), Mymensingh-2202, Bangladesh
\end{abstract}

*Corresponding Author: phone: +8801688557408, Email: tipubari2013@yahoo.com

Received 25 December 2020; Accepted 03 February 2021

\begin{abstract}
The study was aimed to examine whether a strip-tillage system with residue retention can minimize nitrogen requirements for wheat and mungbean crops. There were two tillage systems - conventional tillage and strip tillage, two residue levels- $20 \%$ and $40 \%$ retention of the previous crop residues and five $\mathrm{N}$ rates - $60 \%$ of recommended fertilizer dose (RFD), 80\% RFD, 100\% RFD, 120\% RFD and 140\% RFD. For wheat, the $40 \%$ residue retention produced $2.37 \mathrm{t}$ $\mathrm{ha}^{-1}$ grain yield and the $20 \%$ residue retention demonstrated $2.05 \mathrm{t} \mathrm{ha}^{-1}$. The highest grain yield being observed at $120 \%$ $\mathrm{N}$ application and the lowest yield at $60 \% \mathrm{~N}$ addition. For mungbean, the grain yield obtained for conventional tillage was $0.80 \mathrm{t} \mathrm{ha}^{-1}$ and for strip-tillage was $0.94 \mathrm{tha}^{-1}$. Residue retention i.e. $40 \%$ residue retention showed higher yield $(0.90$ $\left.\mathrm{t} \mathrm{ha}^{-1}\right)$ compared to $20 \%$ residue retention $\left(0.84 \mathrm{tha}^{-1}\right)$. The highest seed yield being observed at $140 \% \mathrm{~N}$ application and the lowest yield at $60 \% \mathrm{~N}$ addition. The interaction effect of residue retention and nitrogen on the seed yield was not significant. For wheat, the highest rate of $\mathrm{N}$ application $\left(140 \mathrm{~kg} \mathrm{~N} \mathrm{ha}^{-1}\right)$ under conventional tillage had the highest seed $\mathrm{N}$ concentration $(2.08 \%)$. For mungbean, the grain $\mathrm{N}$ concentration only varied between two tillage systems and for two interactions such as tillage with different $\mathrm{N}$ rates and residue retention with different $\mathrm{N}$ rates. The contribution of strip tillage and higher residue retention immobilized $\mathrm{N}$ and increased the fertilizer $\mathrm{N}$ requirement.
\end{abstract}

Keywords: Mungbean, Nitrogen, Residue retention, Tillage, Wheat

\section{INTRODUCTION}

A major constraint for higher crop production in Bangladesh is the depletion of soil fertility. The key success of achieving higher and sustainable crop yield is the optimum use of fertilizers along with good management practices such as tillage and residue management. Nitrogen is the most limiting nutrient element in Bangladesh soils because of low soil organic matter content. Among the fertilizers used in Bangladesh, urea alone contributes about $75 \%$ and it is predominantly used in rice cultivation which occupies nearly $80 \%$ of the cultivable land (Jahiruddin et al., 2009).

An emerging approach in Bangladesh agriculture is minimum tillage for optimizing crop yields, with economic and environmental benefits. This practice can slow the breakdown of plant residues and reduce the release of mineralized inorganic forms of plant nutrients in the soil (Hobbs et al., 2008; Kassam et al., 2009). Minimum tillage has a number of advantages. It reduces crop establishment costs, decreases environmental pollution, promotes conjunctive use of organics (avoids residue burning), improves soil health, helps timeliness of field operations and promotes timely planting of crops compared to conventional tillage systems. On the other hand, minimum tillage improves soil tilth, improves water \& air quality, increases soil organic matter and soil biological diversity, reduces soil erosion (Beck 1990; Freebairn et al., 1993; Reicosky, 1997; Baker et al., 2005), improves soil porosity and thus prolongs the availability of plant-available soil water (Stewart, 2007; Derpsch, 2008). 
Under conservation tillage, nitrogen mineralization rate tends to be lower since the soil is not as greatly disturbed and the organic residues remain on the surface where decomposition is slower (Jahiruddin et al., 2009). Therefore, there is usually less nitrate in the unfertilized soil under no-tillage as compared to similar conventionally tilled soil. Hence, nitrogen in the systems tends to be less available under no-tillage, at least in the initial years after conversion from full tillage. It is possible that delaying the application of nitrogen under no-tillage may help avoid early losses of $\mathrm{N}$ due to denitrification and leaching.

The practice of conservation tillage can minimize the rapid breakdown of plant residues and reduce the production of inorganic forms of plant nutrients in the soil. During the decomposition process, the organic N (e.g. protein, nucleic acids) is converted into inorganic $\mathrm{N}$, mainly ammonium $\left(\mathrm{NH}^{+}\right)$and nitrate $\left(\mathrm{NO}^{3-}\right)$ which are readily available to plants. In this process, some soil bacteria (Nitrosomonas, Nitrobacter) are involved. The continuous cultivation of puddled rice has resulted in deterioration of soil health and declination of the water table in Bangladesh. This needs due attention for the sustainability of soil health and satisfactory crop production. Conservation agriculture practice, accompanied by cereal pulse cropping system could help the situation. Conservation agriculture is characterized by minimum tillage with crop residue cover and suitable crop rotation.

Furthermore, no data are available to assess the requirement for nitrogen fertilizer under conservation tillage systems for the wheat-mungbean cropping system in Bangladesh. With the above point in view, the present research was undertaken towards determining the optimum rate of nitrogen application for higher yield of wheat and mungbean and to examine the quality of wheat, and mungbean grains for different rates of nitrogen application under strip-tillage system with residue retention.

\section{MATERIALS AND METHODS}

\subsection{Experimental site}

The experiment was conducted from November 2014 to June 2015 at Soil Science Field Laboratory, Bangladesh Agricultural University (BAU), which is located rural surroundings 3 kilometers (1.9 mi) south of the district town of Mymensingh, Bangladesh (latitude 24.7196 and longitude 90.4267). Chemical analysis of grain samples was done at Soil Chemistry Laboratory, BAU. The land belongs to the Old Brahmaputra Floodplain agro-ecological zone (AEZ 9). It is a medium high land having non-calcareous dark grey floodplain soil (FAO and UNDP, 1988). The soil in the experimental fields at $0-15-\mathrm{cm}$ depth was silt loam in texture with $\mathrm{pH}$ of 6.9 , organic carbon of $2.82 \%$, sand of $11.65 \%$, silt of $75.70 \%$, and clay of $12.65 \%$. The experimental area has a sub-tropical humid climate and is characterized by high temperature accompanied by maximum rainfall during summer and low temperature with minimum rainfall during winter. Weather (rainfall and thermal condition) data were collected from the nearest weather station and are presented in Figure 1.

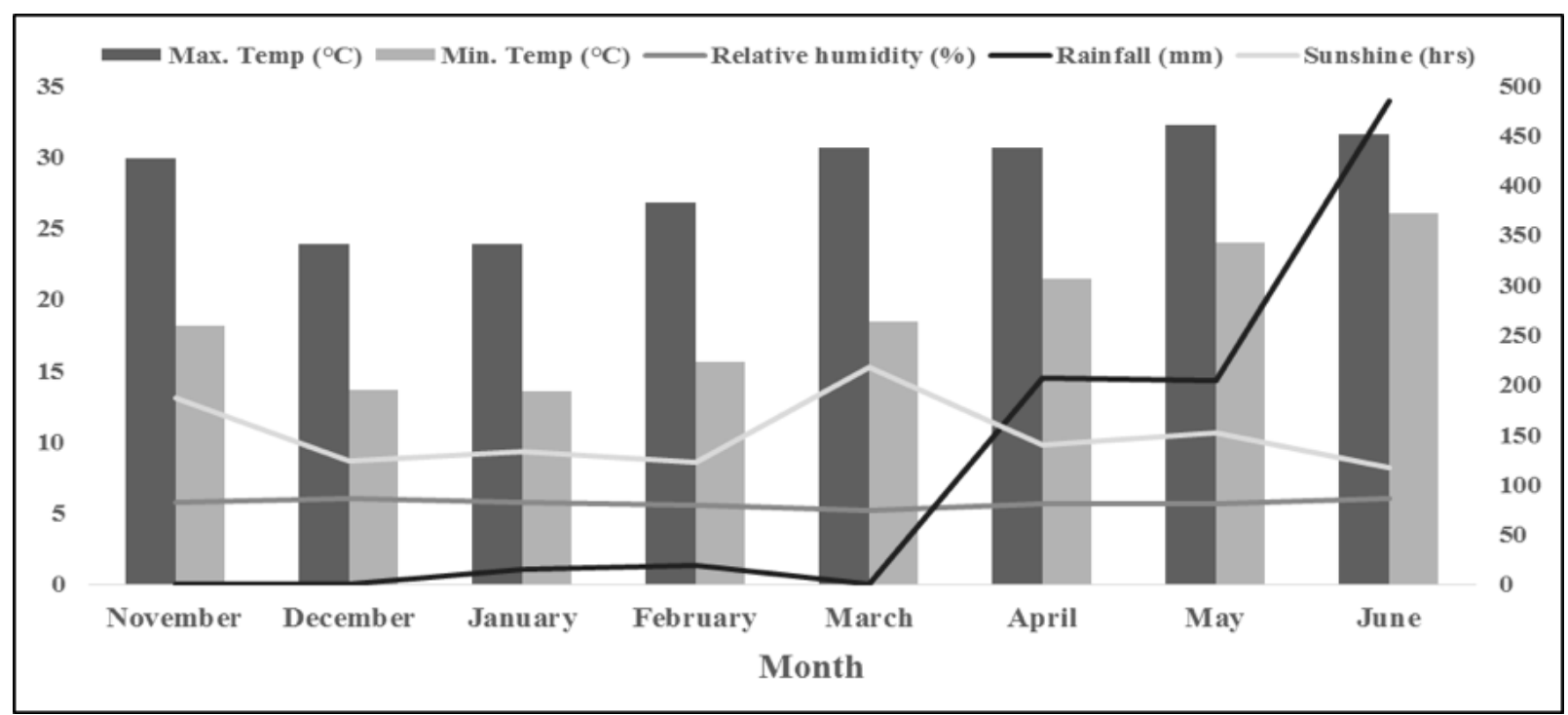

Figure 1: Monthly average temperature, rainfall, relative humidity and sunshine during the research period (November 2014 to June 2015) at BAU campus, Mymensingh

\subsection{Experimental Design}


This was a 3-factorial experiment, Factor A: tillage; two tillage practices i.e. Strip tillage (unpuddled system) and Conventional tillage (puddled system), Factor B: residue retention; two residue retention schemes i.e. $40 \%$ \& $20 \%$ retention of T. Aman rice straw (previous crop) for wheat and $40 \% \& 20 \%$ retention of wheat straw for mungbean, Factor C: nitrogen rates; five levels of nitrogen i.e. $\mathrm{N}_{1}: 60 \%$ of recommended fertilizer-N dose (RFD), $\mathrm{N}_{2}: 80 \%$ RFD, N $\mathrm{N}_{3}: 100 \%$ RFD, N : $120 \%$ RFD, N $5: 140 \%$ RFD. The $100 \% \mathrm{~N}$ rate was $100 \mathrm{~kg} \mathrm{ha}^{-1}$ for wheat and 20 $\mathrm{kg} \mathrm{ha}^{-1}$ for mungbean. Other nutrients were used at the rate of $20 \mathrm{~kg} \mathrm{P}, 60 \mathrm{~kg} \mathrm{~K}, 10 \mathrm{~kg} \mathrm{~S}, 1.5 \mathrm{~kg} \mathrm{Zn}$ and $1.5 \mathrm{~kg} \mathrm{~B}$ per hectare for wheat, and $20 \mathrm{~kg} \mathrm{P}, 30 \mathrm{~kg} \mathrm{~K}$ and $10 \mathrm{~kg} \mathrm{~S}$ per hectare for mungbean. The sources of added nutrients were urea for N, TSP for P, MoP for K, gypsum for S, zinc oxide ( $\mathrm{ZnO}$ ) for $\mathrm{Zn}$ and boric acid for B.

The experiment was laid out in a split-plot design with three replications. The size of the individual plot was $7 \mathrm{~m}$ x $7 \mathrm{~m}$ (49 sqm). Block to block and plot to plot distance were maintained at $1.0 \mathrm{~m}$ and $0.5 \mathrm{~m}$, respectively. The $\mathrm{N}$ rates were randomly distributed to the unit plots under the main plot. Land preparation was done by ploughing and cross-ploughing with a power tiller in the case of conventional tillage plots. In the case of strip tillage, the VMP (Versatile Multi-Crop Planter) was used with a row spacing of $20 \mathrm{~cm}$. BARI Gom 25 was used as a test variety of wheat, and Binamoog-8 as that of mungbean. Seeds of BARI Gom 25 were sown in the experimental plots on 25 November 2014, and Binamoog-8 on 25 March 2015. Before sowing, the whole field was sprayed with 'Roundup' (glyphosate) herbicide to destroy all kinds of weed. Wheat was harvested on 16 March 2015, and mungbean twice on 10 and 14 June 2015. The wheat crop was harvested keeping the straw at $20 \%$ and $40 \%$ plant height in two parts within a plot for use in the next crop (mungbean) experiment.

\subsection{Data Analysis}

The data were recorded on 1000 grain weight $(\mathrm{g})$, grain yield $\left(\mathrm{t} \mathrm{ha}^{-1}\right)$, and grain $\mathrm{N}$ content $(\%)$ for both wheat and mungbean. Nitrogen concentration was determined by following the micro-Kjeldahl method (Kirk, 1950). The data were analyzed statistically by using F-statistics. The mean comparison was adjudged by Duncan's Multiple Range Test (Gomez and Gomez, 1984).

\section{RESULTS AND DISCUSSION}

\subsection{Main Effects of tillage, residue retention and Nitrogen rates on wheat}

\subsubsection{Effects of tillage}

There was no significant effect of tillage on 1000-grain weight, grain yield and grain $\mathrm{N}$ concentration of wheat. However, higher grain weight $(41.60 \mathrm{~g})$ and higher grain $\mathrm{N}$ concentration $(1.97 \%)$ were found in conventional tillage but higher grain yield $\left(2.24 \mathrm{t} \mathrm{ha}^{-1}\right)$ was observed in the strip-tillage system (Table 1). In the case of mungbean, there was no significant effect of tillage on 1000-grain weight but grain yield and grain $\mathrm{N}$ concentration differ significantly. The higher grain yield $\left(0.94 \mathrm{t} \mathrm{ha}^{-1}\right)$ and higher grain $\mathrm{N}$ concentration $(3.95 \%)$ were found in the strip-tillage system (Table 1). Strip tillage has been shown to promote warming within the seed zone because it allows more of the energy of the sun to reach the soil surface (Rechard et. al., 2009).

\subsubsection{Effects of residue retention}

The 1000-grain weight and grain $\mathrm{N}$ concentration of wheat did not differ significantly with two levels of residue retention, although higher values were noted with $40 \%$ residue retention $(41.50 \mathrm{~g})$ (Table 1). For $40 \%$ residue retention, the higher grain yield of wheat was observed $\left(2.37 \mathrm{t} \mathrm{ha}^{-1}\right)$ which was highly significant. The grain $\mathrm{N}$ concentration of wheat did not differ significantly for the two levels of residue retention. There was no significant effect of residue retention on 1000-grain weight, grain yield and grain $\mathrm{N}$ concentration of mungbean (Table 1). The higher grain yield $\left(0.90 \mathrm{t} \mathrm{ha}^{-1}\right)$ was found in $40 \%$ residue retention whereas the higher 1000-grain weight $(32.60 \mathrm{~g})$ and grain $\mathrm{N}$ concentration $(3.96 \%)$ was observed in $20 \%$ residue retention. The increase in yield in more residue retention may be due to improvement in organic matter content of soil and water use by the crop (Wisal et. al., 2010).

\subsubsection{Effects of Nitrogen rates}

The effect of different rates of $\mathrm{N}$ application on 1000-grain weight, grain yield and grain $\mathrm{N}$ concentration of wheat was found highly significant (Table 1). The 1000-grain weight ranged from $40.00 \mathrm{~g}$ to $42.54 \mathrm{~g}$ due to different rates of $\mathrm{N}$ application. The highest 1000 -grain weight $(42.54 \mathrm{~g})$ being observed at $100 \%$ of recommended $\mathrm{N}$ application which was statistically similar to $120 \% \mathrm{~N}$ application (42.38 g). The lowest 1000-grain weight (40.00 g) was recorded at $60 \% \mathrm{~N}$ application. 
The grain yield of wheat markedly varied with different rates of $\mathrm{N}$ application. It was noted that the highest grain yield $\left(2.44 \mathrm{t} \mathrm{ha}^{-1}\right)$ was due to $120 \%$ rate and the lowest yield $\left(1.92 \mathrm{t} \mathrm{ha}^{-1}\right)$ due to $60 \%$ rate of $\mathrm{N}$ application (Table 1). The $\mathrm{N}$ concentration in wheat grain ranged from $1.84 \%$ to $2.08 \%$ across the rates of $\mathrm{N}$ application. The $140 \% \mathrm{~N}$ rate demonstrated the highest grain $\mathrm{N}$ concentration $(2.08 \%)$ which was significantly different from all other $\mathrm{N}$ rates, except $120 \% \mathrm{~N}$ rate $(2.02 \%)$. The $60 \% \mathrm{~N}$ rate exhibited the lowest grain $\mathrm{N}$ concentration $(1.84 \%)$ (Table 1).

In the case of mungbean, the effects of different rates of $\mathrm{N}$ application on 1000-grain weight, grain yield and grain $\mathrm{N}$ concentration were significant. The highest 1000-grain weight $(33.55 \mathrm{~g})$ being observed at $140 \%$ of recommended $\mathrm{N}$ application which was statistically similar to $60 \% \mathrm{~N}$ application (33.48 g). The lowest 1000 -grain weight $(31.07 \mathrm{~g})$ was recorded at $100 \%$ of the recommended $\mathrm{N}$ application. The $\mathrm{N}$ application at $140 \%$ of the recommended rate produced the highest grain yield $\left(1.13 \mathrm{t} \mathrm{ha}^{-1}\right)$ over the other $\mathrm{N}$ application rates (Table 1). The $\mathrm{N}$ concentration in mungbean seed ranged from $3.85 \%$ to $4.03 \%$ among the rates of $\mathrm{N}$ application and varied significantly. The highest seed $\mathrm{N}$ concentration (4.03\%) was found at $120 \% \mathrm{~N}$ rate which was followed by $80 \% \mathrm{~N}$ rate and significantly different from other $\mathrm{N}$ rates. The lowest seed $\mathrm{N}$ concentration $(3.85 \%)$ was observed in both $60 \%$ and $100 \% \mathrm{~N}$ application rates which were statistically similar to $140 \% \mathrm{~N}$ rates (Table 1 ).

A quiet response in grain yield to increasing $\mathrm{N}$ application is often associated with an increase in grain $\mathrm{N}$ content (Asseng et al., 2002). This means that researchers and growers be likely to apply more $\mathrm{N}$ fertilizer than is needed to produce optimum grain $\mathrm{N}$ content in order to ensure a high grain yield. This study suggests that the proper application rate of $\mathrm{N}$ fertilizer is required to accomplish both optimal grain $\mathrm{N}$ concentration and high grain yield.

Table 1: Effects of tillage systems, residue retention and $\mathrm{N}$ rates on different parameters of wheat (cv. BARI Gom 25) and mungbean (cv. Binamoog-8)

\begin{tabular}{|c|c|c|c|c|c|c|}
\hline \multirow[b]{2}{*}{ Treatments } & \multicolumn{3}{|c|}{ Wheat } & \multicolumn{3}{|c|}{ Mungbean } \\
\hline & $\begin{array}{l}\text { 1000-grain } \\
\text { weight }(\mathrm{g})\end{array}$ & $\begin{array}{l}\text { Grain yield } \\
\qquad\left(\mathrm{t} \mathrm{ha}^{-1}\right)\end{array}$ & $\begin{array}{c}\text { Grain } \mathrm{N} \\
\text { concentration } \\
(\%)\end{array}$ & $\begin{array}{l}\text { 1000-grain } \\
\text { weight }(\mathrm{g})\end{array}$ & $\begin{array}{l}\text { Grain yield } \\
\left(\mathrm{t} \mathrm{ha}^{-1}\right)\end{array}$ & $\begin{array}{c}\text { Grain N } \\
\text { concentration }(\%)\end{array}$ \\
\hline \multicolumn{7}{|l|}{ Tillage } \\
\hline $\mathrm{CT}$ & 41.60 & 2.17 & 1.97 & 32.60 & $0.80 \mathrm{~b}$ & $3.88 \mathrm{~b}$ \\
\hline ST & 41.32 & 2.24 & 1.95 & 32.40 & $0.94 \mathrm{a}$ & $3.95 \mathrm{a}$ \\
\hline $\mathrm{CV} \%$ & 3.68 & 15.05 & 5.35 & 4.30 & 18.94 & 3.73 \\
\hline Significance & NS & NS & NS & NS & $* *$ & $* *$ \\
\hline \multicolumn{7}{|c|}{ Residue retention } \\
\hline $40 \%$ residue & 41.50 & $2.37 \mathrm{a}$ & 1.93 & 32.40 & 0.90 & 3.87 \\
\hline $20 \%$ residue & 41.43 & $2.05 \mathrm{~b}$ & 1.99 & 32.60 & 0.84 & 3.96 \\
\hline $\mathrm{CV} \%$ & 3.68 & 15.05 & 5.35 & 4.30 & 18.94 & 3.73 \\
\hline Significance & NS & $* *$ & NS & NS & NS & NS \\
\hline \multicolumn{7}{|l|}{$\mathrm{N}$ rates } \\
\hline $60 \%$ RFD & $40.00 \mathrm{c}$ & $1.92 \mathrm{~b}$ & $1.84 \mathrm{~d}$ & $33.48 \mathrm{a}$ & $0.57 \mathrm{c}$ & $3.85 \mathrm{~b}$ \\
\hline $80 \%$ RFD & $41.60 \mathrm{ab}$ & $2.10 \mathrm{ab}$ & $1.88 \mathrm{~cd}$ & $31.76 b c$ & $0.79 b c$ & $3.96 \mathrm{ab}$ \\
\hline $100 \%$ RFD & $42.54 \mathrm{a}$ & $2.32 \mathrm{ab}$ & $1.95 \mathrm{bc}$ & $31.07 \mathrm{c}$ & $0.88 \mathrm{ab}$ & $3.85 \mathrm{~b}$ \\
\hline $120 \%$ RFD & $42.38 \mathrm{a}$ & $2.44 \mathrm{a}$ & $2.02 \mathrm{ab}$ & $32.63 \mathrm{ab}$ & $0.97 \mathrm{ab}$ & $4.03 \mathrm{a}$ \\
\hline $140 \%$ RFD & $40.78 b c$ & $2.27 \mathrm{ab}$ & $2.08 \mathrm{a}$ & $33.55 \mathrm{a}$ & $1.13 \mathrm{a}$ & $3.87 \mathrm{~b}$ \\
\hline $\mathrm{CV} \%$ & 3.68 & 15.05 & 5.35 & 4.30 & 18.94 & 3.73 \\
\hline Significance & $* *$ & $* *$ & $* *$ & $* *$ & $* *$ & $*$ \\
\hline
\end{tabular}

$\mathrm{CT}=$ Conventional tillage, $\mathrm{ST}=$ Strip tillage, $\mathrm{RFD}=$ Recommended Fertilizer Dose, $\mathrm{CV}=$ Coefficient of variation, $\mathrm{NS}=\mathrm{Not}$ significant, $*=\mathrm{P}<0.05, * *=$ $\mathrm{P}<0.01$

Values having same letter in a column do not differ significantly at $5 \%$ level by LSD.

\subsection{Interaction effects of tillage $\times \mathrm{N}$ rate and residue retention $\times \mathrm{N}$ rate on wheat and mungbean}

The interaction effects of tillage $\times \mathrm{N}$ rate and residue retention $\times \mathrm{N}$ rate on different parameters of wheat and mungbean are shown in Tables 2 and Table 3, respectively. It shows that no interaction effects were significant for wheat. This indicates that tillage, residue and $\mathrm{N}$ effects were independent of the parameters studied. However, the highest 1000 -grain weight $(44.13 \mathrm{~g})$ was found at $40 \%$ residue retention of the previous crop with $100 \%$ of recommended $\mathrm{N}$ application. The highest grain yield $\left(2.64 \mathrm{t} \mathrm{ha}^{-1}\right)$ was observed at $40 \%$ residue retention with $120 \%$ of recommended $\mathrm{N}$ rates. The highest grain $\mathrm{N}$ concentration (2.08\%) was obtained from $140 \%$ of the recommended $\mathrm{N}$ application at the conventional tillage system. In the case of mungbean, the 1000-grain weight, grain yield and grain $\mathrm{N}$ concentration were affected by their interactions demonstrating that strip-tillage performed better results at a higher rate of $\mathrm{N}$ addition compared to conventional tillage (Tables 3). The highest 1000-grain weight (33.95 g) was found from $140 \%$ of recommended $\mathrm{N}$ application at conventional tillage. The highest grain yield $\left(1.35 \mathrm{t}^{-1}\right)$ 
was observed at strip-tillage system with $140 \%$ of recommended $\mathrm{N}$ rates. The highest grain $\mathrm{N}$ concentration $(4.13 \%)$ was obtained from $120 \%$ of recommended $\mathrm{N}$ rates at the conventional tillage system. It points that the effect of tillage systems and residue levels on the reduction of $\mathrm{N}$ rate may not be possible within a short time (2-3 years), it may take more than 3 years to obtain any visible effect.

Table 2: Interaction effects of tillage systems, residue retention and $\mathrm{N}$ rates on different parameters of wheat (cv. BARI Gom 25)

\begin{tabular}{|c|c|c|c|c|c|c|c|c|c|c|c|c|}
\hline \multirow{3}{*}{$\mathrm{N}$ rates } & \multicolumn{6}{|c|}{ Tillage } & \multicolumn{6}{|c|}{ Residue retention } \\
\hline & \multicolumn{2}{|c|}{$\begin{array}{l}\text { 1000-grain } \\
\text { weight }(\mathrm{g})\end{array}$} & \multicolumn{2}{|c|}{$\begin{array}{c}\text { Grain yield } \\
\left(\mathrm{t} \mathrm{ha}^{-1}\right)\end{array}$} & \multicolumn{2}{|c|}{$\begin{array}{c}\text { Grain N } \\
\text { concentration }(\%) \\
\end{array}$} & \multicolumn{2}{|c|}{$\begin{array}{l}\text { 1000-grain weight } \\
(\mathrm{g})\end{array}$} & \multicolumn{2}{|c|}{$\begin{array}{c}\text { Grain yield } \\
\left(\mathrm{t} \mathrm{ha}^{-1}\right)\end{array}$} & \multicolumn{2}{|c|}{$\begin{array}{c}\text { Grain N } \\
\text { concentration }(\%)\end{array}$} \\
\hline & CT & ST & CT & ST & CT & ST & $40 \%$ & $20 \%$ & $40 \%$ & $20 \%$ & $40 \%$ & $20 \%$ \\
\hline $60 \%$ RFD & 39.27 & 40.73 & 1.82 & 2.02 & 1.78 & 1.81 & 39.73 & 40.26 & 2.06 & 1.77 & 1.80 & 1.75 \\
\hline $80 \%$ RFD & 41.41 & 41.78 & 2.08 & 2.11 & 1.96 & 1.92 & 40.87 & 42.32 & 2.23 & 1.96 & 1.94 & 1.95 \\
\hline $100 \%$ RFD & 43.98 & 41.10 & 2.23 & 2.41 & 1.99 & 1.93 & 44.13 & 40.95 & 2.43 & 2.21 & 1.95 & 1.96 \\
\hline $120 \%$ RFD & 42.91 & 41.86 & 2.43 & 2.45 & 2.05 & 1.99 & 41.35 & 43.42 & 2.64 & 2.23 & 1.98 & 2.06 \\
\hline $140 \%$ RFD & 40.45 & 41.12 & 2.31 & 2.24 & 2.08 & 2.01 & 41.35 & 40.22 & 2.47 & 2.08 & 1.99 & 2.07 \\
\hline $\mathrm{CV} \%$ & \multicolumn{2}{|c|}{3.68} & \multicolumn{2}{|c|}{15.05} & \multicolumn{2}{|c|}{5.35} & \multicolumn{2}{|c|}{3.68} & \multicolumn{2}{|c|}{15.05} & \multicolumn{2}{|c|}{5.35} \\
\hline Significance & \multicolumn{2}{|c|}{ NS } & \multicolumn{2}{|c|}{ NS } & \multicolumn{2}{|c|}{ NS } & \multicolumn{2}{|c|}{ NS } & \multicolumn{2}{|c|}{ NS } & \multicolumn{2}{|c|}{ NS } \\
\hline
\end{tabular}

$\mathrm{CT}=$ Conventional tillage, $\mathrm{ST}=$ Strip tillage, $\mathrm{RFD}=$ Recommended Fertilizer Dose, $\mathrm{CV}=$ Coefficient of variation, NS = Not significant

Table 3: Interaction effects of tillage systems, residue retention and $\mathrm{N}$ rates on different parameters of mungbean (cv. Binamoog-8)

\begin{tabular}{|c|c|c|c|c|c|c|c|c|c|c|c|c|}
\hline \multirow{3}{*}{$\mathrm{N}$ rates } & \multicolumn{6}{|c|}{ Tillage } & \multicolumn{6}{|c|}{ Residue retention } \\
\hline & \multicolumn{2}{|c|}{$\begin{array}{l}\text { 1000- grain } \\
\text { weight }(\mathrm{g})\end{array}$} & \multicolumn{2}{|c|}{$\begin{array}{l}\text { Grain yield } \\
\left(\mathrm{t} \mathrm{ha}^{-1}\right)\end{array}$} & \multicolumn{2}{|c|}{$\begin{array}{c}\text { Grain N } \\
\text { concentration (\%) }\end{array}$} & \multicolumn{2}{|c|}{$\begin{array}{l}\text { 1000- grain } \\
\text { weight }(\mathrm{g})\end{array}$} & \multicolumn{2}{|c|}{$\begin{array}{l}\text { Grain yield } \\
\qquad\left(\mathrm{t} \mathrm{ha}^{-1}\right)\end{array}$} & \multicolumn{2}{|c|}{$\begin{array}{c}\text { Grain } \mathrm{N} \\
\text { concentration } \\
(\%)\end{array}$} \\
\hline & CT & ST & $\mathrm{CT}$ & ST & CT & ST & $40 \%$ & $20 \%$ & $40 \%$ & $20 \%$ & $40 \%$ & $20 \%$ \\
\hline $60 \%$ RFD & 33.55 & 33.42 & 0.56 & 0.58 & 3.85 & 3.86 & 33.57 & 33.40 & 0.57 & 0.56 & 3.75 & 3.96 \\
\hline $80 \%$ RFD & 32.62 & 30.90 & 0.76 & 0.82 & 4.08 & 3.83 & 31.70 & 31.82 & 0.80 & 0.77 & 3.92 & 4.00 \\
\hline $100 \%$ RFD & 30.43 & 31.72 & 0.79 & 0.97 & 3.87 & 3.83 & 30.82 & 31.33 & 0.88 & 0.88 & 3.78 & 3.93 \\
\hline $120 \%$ RFD & 32.47 & 32.80 & 1.01 & 0.94 & 4.13 & 3.93 & 32.17 & 33.10 & 1.03 & 0.93 & 4.03 & 4.03 \\
\hline $140 \%$ RFD & 33.95 & 33.15 & 0.90 & 1.35 & 3.80 & 3.93 & 33.75 & 33.35 & 1.21 & 1.04 & 3.86 & 3.87 \\
\hline $\mathrm{CV} \%$ & \multicolumn{2}{|c|}{4.30} & \multicolumn{2}{|c|}{18.94} & \multicolumn{2}{|c|}{3.73} & \multicolumn{2}{|c|}{4.30} & \multicolumn{2}{|c|}{18.94} & \multicolumn{2}{|c|}{3.73} \\
\hline Significance & \multicolumn{2}{|c|}{$*$} & \multicolumn{2}{|c|}{$* *$} & \multicolumn{2}{|c|}{$*$} & \multicolumn{2}{|c|}{$* *$} & \multicolumn{2}{|c|}{ NS } & \multicolumn{2}{|c|}{$* *$} \\
\hline
\end{tabular}

$\mathrm{CT}=$ Conventional tillage, $\mathrm{ST}=$ Strip tillage, $\mathrm{RFD}=$ Recommended Fertilizer Dose, $\mathrm{CV}=$ Coefficient of variation, NS $=$ Not significant, $*=\mathrm{P}<0.05, * *=$ $\mathrm{P}<0.01$

\section{CONCLUSION}

The grain yield did not vary over the two tillage systems (CT and ST) for wheat, but the mungbean strip-tillage system produced a higher seed yield than the conventional tillage system. In the case of residue retention, $40 \%$ residue retention performed better than $20 \%$ residue retention for wheat grain yield, but it did not affect the seed yield of mungbean. Application of $120 \%$ of recommended $\mathrm{N}$ showed better performance on the grain yield of wheat but in the case of mungbean, $140 \% \mathrm{~N}$ produced the maximum seed yield. Conservation agriculture has a clear benefit over conventional agriculture. So, labor and fuel can be saved. With the advancement of time, the contribution of strip tillage and higher residue retention to the crop yield would be visible. 
Acknowledgment: The authors wish to thank the supporting staff of the Department of Soil Science, Bangladesh Agricultural University for their cordial cooperation during $\mathrm{N}$ analyses in seed samples.

Conflict of Interest: The authors declare that there is no conflict of interest.

\section{REFERENCES}

Baker, J.B., Southard, R.J. and Mitchell, J.P. (2005). Agricultural dust production and composition in standard and conservation tillage systems in the San Joaquin Valley. Journal of Environmental Quality, 34: 1260-1269.

Beck, D.L. (1990). No-till guidelines for the arid and semi-arid prairies. Soil and Tillage Research, 9: 307-316.

Derpsch, R. (2008). No-tillage and conservation agriculture: A progress report. In: T. Goddard, M.A. Zoebisch, Y.T. Gan, W. Ellis, A. Watson, S. Sombatpanit (eds.). No-till Farming Systems, pp. 7-39. World Association of Soil and Water Conservation, Bangkok.

FAO and UNDP. (1988). Land Resources Appraisal of Bangladesh for Agricultural Development. Report 2. Agroecological Regions of Bangladesh FAO, UNDP, Rome. 116p.

Freebairn, D.M., Loch, R.J. and Cogle, A.L. (1993). Tillage methods and soil and water conservation In Australia. Soil and Tillage Research, 27: 303-325.

Gomez, K.A. and Gomez, A.A. (1984). Statistical Procedure for Agricultural Research. 2nd Ed. John Wiley and Sons, New York. 67-215p.

Hobbs, P.R., Sayre, K. and Gupta, R. (2008). The role of conservation agriculture in sustainable agriculture. Phil. Trans. R. Soc. Lond., B. Biol. Sci., 363: 543-555.

Jahiruddin, M., Islam, M.R. and Miah, M.A.M. (2009). Constraints of Farmers' Access to Fertilizer for Food Production. Final Report. National Food Policy Capacity Strengthening Programme. FAO, Dhaka, Bangladesh. 52p.

Kassam, A., Friedrich, T., Shaxson, F. and Pretty, J. (2009). The spread of conservation Agriculture: justification, sustainability and uptake. International Agriculture Sustainability, 7: 292-320.

Kirk, P.L. (1950). Kjeldahl method for total nitrogen. Anal. Chem., 22: 354-358.

Rechard, W., Thomas, C. and James, L. (2009). Strip-tillage: A conservation option for Wisconsin farmers. University of Wisconsin-Extension, Cooperative Extension, Madison, WI. A3883, 1-6p.

Reicosky, D.C. (1997). Tillage-induced $\mathrm{CO}_{2}$ emission from soil. Nutrient Cycling in Agroecosystems, 49: 273-285.

Stewart, B.A. (2007). Water conservation and water use efficiency in dry lands. A paper presented in the International Workshop on Conservation Agriculture for Sustainable Land Management to Improve the Livelihood of People in Dry Areas. 7-9 May 2007. ACSAD and GTZ, Damascus, Syria: 57-66.

Wisal, M., Samreen, S., Mahmood, S.S. and Zahir, S. (2010). Effect of tillage and crop residues management on mungbean (Vigna radiata (1.) Wilczek) crop yield, nitrogen fixation and water use efficiency in rainfed areas. Pak. J. Bot., 42(3): 1781-1789. 